Botterill, K. (2018) Rethinking "community” relationally: Polish communities in Scotland before and after Brexit. Transactions of the Institute of British Geographers, 43(4), pp. 540-554.

There may be differences between this version and the published version. You are advised to consult the publisher's version if you wish to cite from it.

This is the peer reviewed version of the following article:

Botterill, K. (2018) Rethinking "community" relationally: Polish communities in Scotland before and after Brexit. Transactions of the Institute of British Geographers, 43(4), pp. 540-554.

(doi: 10.1111/tran.12249)

This article may be used for non-commercial purposes in accordance with Wiley Terms and Conditions for Self-Archiving.

http://eprints.gla.ac.uk/ $171643 /$

Deposited on: 13 August 2018

Enlighten - Research publications by members of the University of Glasgow http://eprints.gla.ac.uk/ 


\title{
Rethinking 'Community' Relationally: Polish communities in Scotland before and after Brexit
}

Kate Botterill, Edinburgh Napier University

\begin{abstract}
Community is a nebulous, contested concept in geography spanning research on social networks, encounters, mobilities, citizenship and belonging. However, its use as a discursive trope in public, policy and academic work points to continued relevance as an analytical category, particularly as meanings of community in Europe are being tested by Brexit. This paper combines diverse scholarship on the geographies of encounter, mobility and citizenship to revisit the concept of 'community' using a relational lens. This is explored through an original empirical analysis of the community practices of Polish nationals in Scotland in the context of Brexit. Using biographical-narrative data collected before and after the UK referendum on EU membership, the paper discusses three forms of community practiced by Polish nationals: community centre, a cyber community, and a community festival. I advance a relational perspective on community that overcomes spatially and temporally rigid dichotomies of communal experience; emphasising community as a dynamic, interconnected and power-laden process involving multiple temporalities.
\end{abstract}

\section{Introduction}

Britain's exit from the EU will repeal the 1972 European Communities Act raising new questions about the nature and legacy of community in Europe. The This paper is the 'accepted' version, now published in Transactions of the Institute of British Geographers 
unprecedented wave of EU-8 migration from Central and Eastern Europe to the UK was a major, though not isolated, factor in the vote to leave the EU (Clarke et al. 2017; Ford and Heath, 2017). The campaign and vote also reignited public, policy and academic debate on European mobilities, citizenship and community. These geopolitical tremors shape the everyday lives of people moving around the EU unsettling attachments to place and nation. However, social relationships, ties and networks are durable and often required in the face of geopolitical crises. Indeed, the use of the term 'community' in public, policy and practitioner discourse surrounding Brexit, as well as its reiterations in research on migration, belonging and citizenship indicate its continued conceptual relevance. People keep coming back to community, as a discourse and a resource in $21^{\text {st }}$ century politics. Despite this, there has been relatively little attention by geographers to theorising community in this context. Contributing to scholarship on the geographies of encounter, mobility and citizenship, this paper develops an empirically-grounded and relational understanding of community - how it is lived and practiced in everyday life, over time and in relation to broad discursive landscapes at a range of sites and scales. Foregrounding the narratives of Polish nationals living in Scotland, this paper provides an original, empirical analysis of the relational community practices before and after the vote for Brexit.

Relationality is at the heart of community in the relationships between people, places and societies, yet many studies of community have tended to be mechanistic, producing spatially and temporally rigid dichotomies of human experience (Studdert and Walkerdine, 2016). The paper makes a significant departure from reductive notions of community that essentialise identities and relationships advancing a This paper is the 'accepted' version, now published in Transactions of the Institute of British Geographers 
relational framework for the study of community. I conceptualise three components to undergird an empirical analysis of community: (1) community is a dynamic, interconnected and power-laden process involving lively forms of co-relating and multi-scalar (dis)connections that are structural, discursive and performative; (2) there are multiple temporalities of community as communal engagements are paced differently across time and the lifecourse; and (3) mobility is central to understanding community and it is made meaningful by the mobile interactions of people, places and things. The paper begins with a discussion of the geographies of community and I draw on diverse scholarship on multicultural encounters, everyday mobilities and citizenship that foreground relational thinking to set up an analytical framework. Following this I briefly outline the context of Polish migration to the UK and discuss three community practices of Polish nationals living in Scotland: the community centre, the cyber community and the community event.

\section{The geographies of community}

Geographical studies of community gained momentum in the early $20^{\text {th }}$ Century within the Chicago School of Human Ecology (Park and Burgess, 1967). Whilst this work did much to establish a relationship between community and place influencing important studies of neighbourhood community (Cater and Jones, 1989), it is heavily critiqued for its universalism, essentialism and assimilationist modelling (Valentine, 2001). Young's (1986) progressive reframing of urban community as incorporating a 'politics of difference', instead, pointed to the complexity and heterogeneity of interactions in the city. This work motivated a 'third phase' in community studies exploring the contextual and interconnected dimensions of community (Crow and This paper is the 'accepted' version, now published in Transactions of the Institute of British Geographers 
Allen, 1994), shifting research directions to the urban geographies of encounter and conviviality which I go on to discuss. Alongside these developments, the concept of neighbourhood community is seen to be either 'lost' in the quagmire of capitalism; 'saved' through micro-scale processes of socialization; or 'liberated' by new virtual and transnational forms community (Valentine, 2001:115).

This thorny and convoluted history has led some to let go of the concept completely, denouncing it as meaningless and romanticized (see Valentine, 2001). Focus shifted instead to social networks, social capital and livelihood approaches, particularly to explain social ties in the context of migration (Ryan et al., 2008; Vertovec, 2001). Yet, others argue that there is much to be gained from a revival of community. Studdert and Walkerdine (2016) argue that community has tended to be understood through spatially and socially rigid dichotomies, rarely capturing the complex, lived experience of 'communal being-ness'. Tönnies (1957) foundational distinction between Geimenschaft and Gesselschaft, they argue, has paved the way for more unhelpful categorisations of community as located or virtual, 'broken' or socialcapital rich (Putnam, 2001), traditional or cosmopolitan (Beck, 2006). For Studdert and Walkerdine (2016) there are four central qualities to community: hybridity, plurality, action and (inter-) relationality. This paper is concerned with the fourth quality of relationality and the following section demonstrates how and why geographers might think relationally about community ${ }^{\mathrm{i}}$.

\section{Rethinking community as relational}

This paper is the 'accepted' version, now published in Transactions of the Institute of British Geographers 
Community is at its heart a relational concept. Writing about communities in Britain, Frankenberg (1966:17) noted that in 'face-to-face communities each individual is related to every other individual in his total network in several different ways'. Calhoun (1998:19) goes further to describe community as 'not a place or simply a small-scale population aggregate, but a mode of relating, variable in extent'. Massey (2005:189) argues that relational thinking avoids 'the pitfalls of classical individualism and of communitarian organicism' because it requires an understanding of space and social life as open and 'always being made'. To some degree, geographers are already thinking relationally about community, notably, by exploring the geographies of encounter in multicultural and 'superdiverse' cities (Amin, 2002; Askins and Pain, 2011; Darling and Wilson, 2016; Noble and Poynting, 2010; Valentine, 2008; Valentine and Sadgrove, 2014; Wilson, 2016). Much of this work explores how individuals negotiate difference in socially diverse societies, seeking to understand the value of everyday encounters for establishing cohesive communities. Gill Valentine's (2008) work, for example, has explored the potential for 'meaningful' contact with difference in sites of multicultural unease, arguing that face-to-face contact does not automatically dispel prejudice. Valentine and Sadgrove (2014) criticize accounts that prioritise the 'fleeting' moments of interaction arguing for more in-depth narrative analysis to explore the multiple temporalities pertaining to past experiences and anticipated futures. Critically, Wilson (2016) has urged for a fuller concept of encounter that accounts for the active, meaning making processes produced through encounters. She argues that encounters are a particular form of relationality, active in the production of difference and sees potential for meaning through the accumulation of encounters and those that are 'sustained' (Matejskova and Leitner, 2011). Alongside this, work on 'conviviality' highlights both similarity This paper is the 'accepted' version, now published in Transactions of the Institute of British Geographers 
and difference in everyday interactions, these are 'relational' and involving boundaries and antagonisms (Gilroy, 2004; Nayak, 2017; Rishpeth and Rogaly, 2017; Rzepnikowska, 2016). These accounts emphasise the historicized, materialized, embodied and sensory dimensions of social interaction attending to both structural and performative registers.

Relational analyses of community are also implicit in many studies of everyday citizenship, migration and mobility (Askins, 2016; Phillips, 2010; Rogaly, forthcoming; Ryan et al., 2008; Staeheli, 2012). Phillips and Robinson (2015) highlight the 'spatial variability, contradictions, and ambiguities' of community in different urban localities; while Staeheli et al. (2012:641) note that citizenship is 'inseparable from the geographies of communities and the networks of relationship that link them, with their attendant inequalities, imperfections, and opportunities'. They discuss how 'ordinary' practices of citizenship involve 'uneasy relationships between individuals, groups, communities, and the state that together constitute citizen-subjects' (635). Going further, Askins (2016:516) develops the concept of 'emotional citizenry' as a challenge to the 'reductive productions' of the citizen as a subject of nation and migration that are so frequently deployed in the formal political sphere. She defines emotional citizenry as the 'already practised, enacting social relations that are precarious and possible' (ibid.). Citizenry is a living and feeling body politic and Askins stresses the importance of emotionality as a lens to understand intercultural encounters relationally - 'through concurrent difference-andsimilarity instead of oppositional and reductive dualisms' (518). This diverse scholarship is connected by a focus on the messy, differentiated and contingent nature of social relationships. Like studies of encounter and conviviality, the structural, This paper is the 'accepted' version, now published in Transactions of the Institute of British Geographers 
discursive and performative are explored together to illustrate entangled webs of relations. Drawing on these works I sketch out three epistemological pillars to undergird a relational reading of community. In doing so I am not aiming to replicate this work, but connect debates surrounding community cohesion, urban citizenship and encounter through the core concept of relationality.

Firstly, a relational perspective rejects community as a normative and rigid sociospatial formation and highlights dynamic, interconnected and power-laden processes. Relational thinking requires a re-definition of space, place and scale (Jones, 2009; Marston, 2000; Massey, 2005; Thrift, 2004). Jones (2009:487-8) argues that relationality is an 'open-ended, actor-centred, and mobile politics of spatiality'. He also summons a re-definition of place as 'a subtle folding together of the distant and the proximate, the virtual and the material, presence and absence, flow and stasis, into a single ontological plane upon which location - a place on the map- has come to be relationally and topologically defined'(ibid.). Relational thinking, thus, also challenges the notion that spatial scales are somehow pre-given or socially produced emphasizing a multiplicity of networks, interconnections and processes of becoming (Leitner, 2012; Marston et al., 2005). Studdert and Walkerdine (2016) argue that theories of community have tended to prioritise particular scalar relations, i.e. individual vs state, at the expense of other realms of investigation. Even in studies of transnational communities that cut across scale, the nation is widely positioned as the relational subject. Through the relational lens, community is not fixed but a dynamic and emergent set of relationships, from 'being-in-the-world' to 'becoming-in-theworld' (Anderson, 2012).

This paper is the 'accepted' version, now published in Transactions of the Institute of British Geographers 
However, while there is emancipatory potential here, questions of power and unevenness linger. Too much emphasis on open-endedness and fluidity could lead to the valorization of some (cosmopolitan) visions of community over others forms of being together. Attempting to bridge poststructuralist work on practice and discourse with a politics of scale, MacKinnon (2010) argues for a fuller understanding of scale that recognises both its material and discursive properties. Here, scale is not inert but malleable and relational. He draws on Smith (1993) to show how 'scales and scalar relations are shaped by the processes of struggle between powerful social actors and subaltern groups' (Mackinnon, 2010:24). In particular, processes of 'scale jumping' and 'scale bending', where social actors traverse or transgress certain scales to achieve political outcomes (Smith, 2004), can be usefully deployed to understand the multiple and shifting scales of community and citizenship. For example, Koefoed and Simonsen (2012) have explored how Pakistani citizens' experiences of estrangement and non-recognition in Copenhagen led to ambivalent identifications with the Danish nation, but positive identifications at alternative spatial scales, such as the city. In a different example, Horschelmann and El Refaie (2014) disrupt scalar logics of cosmopolitan citizenship by exploring the citizenship practices and political identities of young people in the UK. Their relational perspective of youth citizenship shows the interconnected scales through which young people actively engage in and perform politics. Similarly, in exploring the 'emotional citizenry' that happens through encounters between refugees, asylum seekers and 'befrienders' in Newcastle Upon Tyne, Askins (2016) suggests that these relational practices 'exceed' the national scale of citizenship and are mediated across spatial scales. Askins illuminates the inter-subjective relations and emotional performances that cut across formalized and normative power structures and 'repoliticise everyday and interpersonal interactions This paper is the 'accepted' version, now published in Transactions of the Institute of British Geographers 
as interwoven through broader (state) politics' (525). These approaches are useful for understanding community (relationally) since they encourage an analysis of the discursive production of community alongside how it is lived, embodied, practiced and transgressed by different actors across space, time and scale. In terms of understanding Brexit and its effects on Polish nationals (and non-British nationals more broadly), it is important to analyse the discourse of national community, produced through interconnected (territorial, institutional and public) frames of meaning, vis-à-vis everyday practices, performances and interactions across scales.

Second, the issue of time and temporality is key to understanding the relational dynamics of community. Communities change over time and involve multiple temporalities. Thinking relationally about community involves analyzing both spatial and temporal interconnections, or as McKinnon (2010:31) puts it, between the 'inherited arrangements and emergent projects and relations'. Despite the relative scarcity of research on community and time (see Bastian, 2014 for review), it widely features as a contextual factor in understanding the dynamics of community (Crow and Allen, 1994). Kenyon (2000:22) argues the that community 'mediates and is mediated by notions and experiences of time'. In her study of 'students' and 'locals' in Sunderland, she highlights the importance of time (as activities, norms, memories, timetables, expectations and experiences) for both permanent and 'temporary' residents as shaping meanings of community. Similarly, in their work on the 'moving' histories of class and community, Rogaly and Taylor (2009:6) use oral history accounts of working class mobilities to explore the connections between places and between classes, and their changes over time'. Indeed, temporal metaphors, such as duration, permanent/temporary, aspiration and expectation, integration and adaptation This paper is the 'accepted' version, now published in Transactions of the Institute of British Geographers 
are frequent references in research on internal, international and return migration. These metaphors relate in one way or another to the complex and relational role of time in the experience, interpretation and dis/continuity of community. For example, Ryan (2017:3) argues that for Polish nationals in the UK, integration and attachment involve 'differentiated embedding', conceptualized as a dynamic, multiscalar and differentiated process i.e. the degree of rootedness to a particular 'sector of society', such as the labour market or the neighbourhood, can vary over time and space. This concept is useful for thinking through the complex, relational processes of Polish community in the context of Brexit. Some argue that Brexit has interrupted the potential futures of EU citizens in the UK, a temporal disjuncture to their continued security as citizens (Lulle et al., 2017). Yet others highlight the feeling of being 'left behind' and excluded is not new and reflects a long-standing discourse of the 'backwardness' of Eastern Europeans (Todorova, 2005).

Work on critical temporalities has shown how those timed-out of particular (hegemonic) continuities might create 'alternative continuities' over time and through embodied and material practices (Bastain, 2014). For migrants, such non-teleological practices might include the strategic deployment of both continuity (tradition) and discontinuity (new methods of cultural translation) in the formation and negotiation of community (Sanadjian, 1995). These approaches encourage analysis of the sensory and embodied experiences of time and community. They enhance the analytical scope of community emphasising multiple temporalities of community that are lived and practiced (Valentine and Sadgrove, 2014), rejecting binaries of permanent/temporary; ephemeral/established; traditional/progressive. Thus, questions arise regarding the pace of community lives, the differential allocation of time within and between This paper is the 'accepted' version, now published in Transactions of the Institute of British Geographers 
communities; and how rhythms of community are shaped by the lifecourse to understand why community matters at particular times of life.

Thirdly, a relational understanding of community involves thinking about mobility. Movement is integral to understanding community relations and 'the unfolding of encounters' (Wilson, 2016:14). The mobilities paradigm, advanced by Sheller and Urry (2006) is a useful conceptual framework to think through mobility and community since it is based on a premise of relationality. Urry (2007:46) views social relationships as a series of connections that are 'more or less 'at a distance', more or less fast, more or less intense and more or less involving physical movement'. This vast body of work is beyond the scope of this paper, but there are two helpful concepts that could aid understanding of community. First, the concept of 'moorings' to describe the spatial, infrastructural and institutional platforms that configure mobility (Hannam et al., 2006). These range from place bound structures, such as roads and airports, to the everyday immobile platform of a desktop PC that enables 'cybermobilities' (Adey and Bevan, 2006) and produce online communities. Whilst these platforms are enabling, moorings are also holding spaces, where people and objects are still or wait for potential mobility (cf. Bissell and Fuller, 2010). Second, there are frictions of mobility - between objects and subject positions that constitute material and emotional worlds in flux and signal the 'erratic' nature of mobility (Adey, 2006:91). For Cresswell (2014:108) friction is 'lived and felt' and enables us to analyse how 'people, things or ideas are slowed down or stopped', whether by choice or force. For migrants, this can range from the strengthening of borders through securitization and surveillance of migrant bodies to the everyday intracommunity tensions that emerge through a lived politics of difference (Cresswell, This paper is the 'accepted' version, now published in Transactions of the Institute of British Geographers 
2010; Valentine, 2008). At the same time friction, Cresswell (2014) declares, also enables mobility - it enacts change and is transformative. Drawing on Tsing, he refers to particularities as important because they make real concepts that are taken as universal. Community is thus made real through 'the particular' where friction happens - in context, in practice and in place and through the 'sticky materiality of practical encounters' (Tsing, 2004:1). A relational theory of community recognizes the sticky moments as significant in processes of becoming. Community then, involves various frictions of mobility, ranging from the everyday frictions between bodies, imaginations and spaces of community to the 'bigger' frictions of political change that facilitate or constrain.

A relational reading of community overcomes dualisms that have long frustrated the study of community and makes visible complex interconnections of scale, time and mobility. This multi-layered analysis acknowledges that the structural and discursive processes that shape communities are connected to the practices and performances of community that are lived, embodied and emotional. In the remainder of this paper, I illustrate this through grounded empirical work with Polish nationals in Scotland and show how their engagements with and perspectives on community are inherently relational.

\section{Understanding Polish communities in Scotland}

Research is emerging on Polish migration to Scotland, largely due to its very different political character and demographic needs (McGhee, Heath, and Trevena, 2012; Piętka-Nykaza and McGhee, 2017). The pace and volume of EU-8 migration has been This paper is the 'accepted' version, now published in Transactions of the Institute of British Geographers 
felt in Scotland but with slightly different results from the rest of the UK. Attitudes to migration in Scotland are perceived to be less hostile than in England (McCollum et al., 2014) and political commitments to increased migration and EU citizen rights have been more encouraging (Scottish Government, 2017). Scholarship on Polish migration has demonstrated its heterogeneous membership and diverse histories and geographies (Burrell, 2009; Garapich and Eade, 2009; Ryan et al., 2008; Stenning and Horschelmann, 2008). Three main waves of Polish migration to the UK have shaped the nature and discourse of Polish community (Galasinksa, 2010). These are, first, post-WW2 migrations made up largely of former soldiers, officers and political exiles who established the infrastructure of Polish community in the UK (Burrell, 2006); second, post-1989 migrations after the fall of communism in Central and Eastern Europe characterized by restricted mobility and struggles of integration (Galaśinska, 2010); and third, post-accession migration following EU enlargement in 2004, which is the focus of this paper.

Post-accession Polish migrants have often been theorized as transient, circular and meritocratic individuals who are generally more educated and economically adaptive than previous generations of Polish migrants (Eade et al., 2007; Engbersen and Snel, 2011). However, critical scholarship contest these characterizations pointing to more 'open-ended' settlement strategies and practices (Piętka-Nykaza and McGhee, 2017; McGhee et al., 2017) and highlighting the centrality of social relations, such as the family, to EU-8 migrants in the UK (Ryan, 2009; Moskal, 2014; White, 2010). Grzymała-Kazłowska (2017) argues that Polish nationals engage in 'social anchoring' to achieve stability and security in the context of adaptation and settlement. Anchoring is a relational process involving the cognitive, behavioural and social This paper is the 'accepted' version, now published in Transactions of the Institute of British Geographers 
actions of migrants as they settle in to a new society. There is no fixed trajectory towards an ideal state of 'integration' but a series of variable connections and disconnections over time. Similarly, Ryan's (2017) concept of 'differential embedding' discussed in the previous section points to the spatial and temporal complexities of building relationships in migration destinations. Others have focused on the different spaces in which community evolves, such as the workplace and the Church (Brown, 2011; Grzymała-Kazłowska, 2005). These spaces are important for social support yet are often marked by institutional, intergenerational, classed, gendered and spiritual frictions (Garapich, 2008b). In the following section I discuss three forms of community and their attendant frictions, based on original empirical research.

\section{Methodology}

This paper uses biographical-narrative data from interviews with EU-8 Polish nationals living in a city in central Scotland. It is based on a broad data set, collected in 2010 with follow up interviews in 2016, exploring the changing experiences of mobility, belonging and community for current and return migrants. Participants were selected through convenience and snowball sampling, sourced through internet forums, local community groups and educational networks. Data collected in 2010 included 32 narrative interviews with follow-up photo elicitation interviews with Polish nationals aged 18-35 in Scotland (16) and Poland (16), 10 semi structured interviews with community representatives, and participant observation captured during one year of volunteering at a community centre in Scotland. In 2016, follow up interviews were conducted with 16 original participants in Scotland (10) and Poland This paper is the 'accepted' version, now published in Transactions of the Institute of British Geographers 
(6). These interviews were unplanned and took place in the context of the UK Referendum on EU membership to capture impacts and future plans of Polish nationals. The interviews were not, however, designed in isolation but reflected prior interview contexts ${ }^{\mathrm{ii}}$. As Ryan and D'Angelo (2017) argue, unplanned follow-up interviews and ongoing engagements in the research field can be a flexible and practical approach to researching the dynamics of migrant community networks. Moreover, analyzing the data through a relational lens directs attention to the diverse temporalities of migrant community. The data was fully transcribed and analysed using thematic analysis in NVivo software. Given the focus of this paper, the data presented here is based on the Scotland-based fieldwork and interviews with 10 Polish nationals who completed both sets of interviews. All data are anonymous, with names of people, organisations and places change to ensure confidentiality of participants.

\section{A Meeting Place: the community centre}

In the 'community wing' of a primary school a weekly drop-in service for the Polish community ran from 2006-2013. Part funded by the city council, the centre aimed to provide a 'safe and secure space for migrants' following incidents of discrimination against EU-8 migrants. Like Polish churches, clubs and societies established following WW2, the community centre was seen by many new arrivals as an important network whilst navigating an unfamiliar city. Jozef, a volunteer who arrived in 2009 and worked as a kitchen porter in a local restaurant, reflects on why this community is meaningful to him.

This paper is the 'accepted' version, now published in Transactions of the Institute of British Geographers 
"I get closer to my people...I feel like someone needs my help. This is so powerful because there is nothing more important than the feeling that someone needs you...I remember after all those years in the kitchen when they push you down and they say 'Polish rubbish'...I feel more like relieved here and I start to do what I really want"' (Jozef, age 33, 2010).

For Jozef, the community centre is a space of co-present interactions offering a sense of purpose and solidarity against past experiences of discrimination. Echoing work by Grzymała-Kazłowska (2017) and Askins (2016), the community centre is viewed as an anchor for social bonding that is structural, interactional and emotional. It is a site of embodied encounter and interdependence that is meaningful across scales - locally placed but related to international contexts and memories (Askins, 2016). Moreover, Jozef narrates community as a site of multiple temporalities, in relation to 'all those years' of xenophobia in the past and a hopeful future where he can 'start to do' what he wants. This type of social bonding is made possible by the material infrastructure of a place to meet, a physical 'mooring' for those seeking to build relationships. Yet, as Massey (2005) argues, place is made through interactions across space and time. While the community centre gives the impression of a neighbourhood community fixed in place, members would travel from across and beyond the locality to participate showing that whilst place is a vital mooring for community, locality is less significant to migrants who are spatially dispersed. Location is relationally defined through the networks and practices of Polish nationals for whom meanings of home and place are shifting (Jones, 2009).

This paper is the 'accepted' version, now published in Transactions of the Institute of British Geographers 
Communication is at the 'heart of community' (Burrell, 2006:167) and communicating in the Polish language was viewed by many members as a vital condition for building relationships and preserving cultural ties. Ewa, a volunteer without children, reflects on the importance of sharing Polish traditions.

"I think it is important, it scares me you know. One woman... we tried to convince this seven-year old girl to read in Polish and to learn Polish letters and stuff and she said 'no, I don't need that, I go to a Scottish school', and we said 'well, do you ever see your Granny and your Grandfather...would you like to write a letter to them, they probably don't speak English', ... 'well yeah ok, maybe', it's stuff like thatotherwise kids just don't really care" (Ewa, age 24, 2010).

Ewa views language and culture as entwined with the requirements of community. The preservation of culture is connected to histories of 'home' and intergenerational relationships. Again, community involves interconnections between multiple temporalities as histories of home and intergenerational relationships map onto children's futures. Spatial scales are also 'bended' as cultural transmission of national identity happens in local spaces, for the benefit of transnational networks (cf. Smith, 2004). Revisiting these themes in 2016 added further complexity. Many people felt that the vote for Brexit had affected the communication practices of Polish nationals in public spaces enhancing the need for alternative community spaces for co-national communication.

"I don't like to talk to Piotr or Alicja in Polish because this, I have, maybe it's my, it's my head again, but I have, sometimes I am being looked at, and sometimes it's This paper is the 'accepted' version, now published in Transactions of the Institute of British Geographers 
just my head. I guess. But certainly I, I think there was a few moments like that where Ifelt what previously [before the referendum] did not alert anyone to pay attention to me... misbehaviour of a child being, you know, talked to in a foreign language does evoke certain nodding, huffing, or you know like, rolling eyes and stuff" (Dorota, age 37, 2016).

For Dorota, finding a safe space to speak Polish became more difficult after Brexit. She discussed this in relation to broader claims of 'fragmented communities', of the 'fuzzy boundaries' between British nationals and 'others' that, she felt, had being validated by the referendum and euroskeptic UK government rhetoric. Dorota's reticence to speak Polish in public reflects a disconnection with her wider neighbourhood community since it exposes a difference that is deemed unacceptable. Her sense of belonging in the city is adrift in relation to both political narratives of rupture and everyday embodied encounters in public space. Many participants expressed feelings of rejection and alienation after the referendum, as other research with EU nationals in the UK has found (Lulle et al, 2017). Anderson and Wilson (2017) argue that Brexit was an 'occasion of dissensus', revealing and producing divisions and cutting through pre-existing commonalities. For others, Brexit strengthened co-national modes of relating as some craved affective solidarities with other Polish nationals immediately after the vote, as Maria claims here.

"when I woke up on Friday and I really found out that the, it was about to leave, without very much understanding what's going to happen, I really felt like I lost a boyfriend. It was the same feeling, like physically and emotionally. I was angry, I was anxious, I really craved the company of other people who are like me, and everybody This paper is the 'accepted' version, now published in Transactions of the Institute of British Geographers 
else there. It was like yeah, it was, it wasn't depression because then you try to be alone, and you just need to find other people, and you take comfort from your community" (Maria, age 36, 2016)

Maria withdraws from cosmopolitan modes of belonging towards the familiar, comforting national frames of belonging, re-positioning her loyalties in reaction to feelings of displacement and mistrust. As Burrell (2006:168) suggests, 'community becomes all the more attractive when the outside world appears hostile'. Drawing on Ryan's (2017) notion of 'differential embedding', there is a variability in Polish migrant attachment to co-national communities at different times. Maria's yearning for the similar is concurrently an attempt to minimize her difference and is a temporary, adaptation strategy to cope with a new feeling of being different as she internalises new racialised hierarchies in the post-referendum landscape (see also Lulle et al., 2017; Fox et al., 2012; Ryan, 2010). As Askins (2016) has argued, there is an emotionality to these strategies and feelings of rejection stimulate both a withdrawal from particular encounters and a re-scaling of community to seek familiar and safer spaces for social bonding.

Migrant community structures are viewed as key sites of 'adaptation' in a host society providing an infrastructure of connection, support and mutuality for the new arrivals or the newly displaced. However, they often rely on the perception of 'sameness' to function which can constrain and obligate individuals to conform to restrictive moral codes (Crow and Allen, 1995), as 'benign social networks' that operate as 'mechanisms of social control' (Burrell, 2006:171). Indeed, geographers have critiqued the ways in which state-sponsored policies of affirmative recognition and This paper is the 'accepted' version, now published in Transactions of the Institute of British Geographers 
inclusion construct rigid ethno-national notions of belonging and essentialise identities (Askins, 2016; Coulthard, 2014). Some participants perceived the centre to be a 'Polish ghetto' (Jacek, age 28) where 'other' Poles would 'huddle together around the Polish centres' and 'get stuck like that' (Lukasz, age 28). Jacek and Łukasz's classed imaginaries of the isolated economic migrant yearning for the Polish homeland is well-documented elsewhere in studies of Polish migration (Ryan, 2010). Galaśinska (2010), for instance, has discussed the inter-generational tensions between different waves of Polish migrants in the UK shaped by diverse migration experiences and judgements made on the basis of history, generation and education. The overlapping experiences of community for these very different individuals produce temporal and scalar tensions between individual claims to belonging and the obligations to build a collective identity (Crow and Allen, 1995). This is also connected to broader political and economic issues of citizenship, mobility, and austerity. In response to dwindling funds, volunteers shifted the remit to a monthly 'multicultural migrant drop in' to diversify membership beyond Polish nationals. Following a slight decline in numbers of Polish arrivals to Scotland in 2010, funding for 'integration' activities had been de-prioritised and as a housing development officer in the Council remarked, 'they are all going home, aren't they?'. Despite policy agendas shaping migrant integration strategies the community centre evolved through the practices and actions of an increasingly diverse group of people until it's closure in 2013 due to lack of premises. The absence of a place for community, however, strengthened other 'emergent' modes of community, which I go on to discuss. The community centre is a relational site of 'throwntogetherness' (Massey, 2005), energized and constrained by frictions of generation, class, gender, politics, history and geography (cf. Garapich, 2008a). The various mutations of the centre This paper is the 'accepted' version, now published in Transactions of the Institute of British Geographers 
signal the dynamism of community and the imaginative mobilities of its members to construct new sites of meaningful interaction.

\section{Virtual and visceral: the cyber community}

In 2007, a year after arriving in Scotland, Tomek and his brother Mariusz set up a Polish community website to 'create a community that, outside of work...is also interested in culture, arts and tourism'. With a dual role of promoting Polish culture to Scots and Scottish culture to Poles, the site is an interactive forum in which its members post links to cultural events in the city. The site aimed to show a city 'rich in opportunity and possibility' and cultivate a sense of 'home' to the Polish 'exiles' living here. Tomek explains here his motivation for building the website.

"The perception that the media creates is so shallow in understanding... there are stereotypes that were created - there was this moment where everyone was coming for money - but the people who are here only for money are back in Poland-they're not here anymore. So people who are here now are quite different I guess" (Tomek, age 30, 2010).

Like Jacek and Lukasz's earlier rejection of 'other' Poles, Tomek clearly dissociates from identifying himself as an economic migrant. This reflects well-documented intergenerational tensions between Polish communities in the UK. Garapich (2008a:7) argues there is a rift between political exiles, whose migration was a 'sacred act in the fight for freedom' and the economic migration as 'cowardice, egoism and an This paper is the 'accepted' version, now published in Transactions of the Institute of British Geographers 
ambiguous act of turning away from the fate of the nation'. This distinction is amplified by a discourse of Polish migrants as either vulnerable low skilled workers or 'benefit tourists' (Hough and Whitehead, 2011). The website offers a relieving antidote to the migrant worker stereotype to reflect the 'people here now', demonstrating an emergent set of connections positioned in complex space-time configurations (Anderson, 2012). The website is an infrastructural 'mooring' to facilitate the virtual interactions between people and community 'without propinquity' (Urry, 2007). However, these interactions are not necessarily at a distance. Web content is based on identification with the city, signposting to real events in place and co-creating multiple spatial scales through which community operates (cf. Koefoed and Simonsen, 2012). 'Within this group we started to meet each other', Tomek says, revealing a corporeal community offline in physical spaces of encounter that involved embodied and sensory investments. The website - as an infrastructural mooring - enabled a dynamic set of relationships to develop in place. For example, Tomek discussed a bi-monthly 'vodka party' that developed as an excuse for cross-national sharing of creative ideas fueled by the national drink of Poland and given meaning through co-present, sensory encounters (Wilson, 2016).

“...Vodka party! It's one of the parties where my friends meet and friends of my friends... this shows something, what kind of environment and at my party there could be a person I don't even know their name. And there is Scottish guy, English guy, Italian guy and a bunch of crazy Polaks and I think that shows quite a lot of how we live here...it's quite inspiring as well and it's also good when there is people from different nations coming over so it's another set of new ideas" (Tomek, age 30, 2010).

This paper is the 'accepted' version, now published in Transactions of the Institute of British Geographers 
This community practice liberates spatial and temporal rigidities as Poles 'transform their immediate spaces into places of familiar rituals, smells and tastes' is viewed as an emotionally symbolic recreation of something lost or distant (Rabikowska and Burrell, 2009, p.216). However, these encounters denote more diverse and 'vitalist modes of being' together (Woodyer and Geoghenan, 2013) where bodies relate in enlivened spaces. This form of community is 'scale bending' as different nationalities connect virtually and co-relate corporeally in local spaces (Smith, 1995). Whilst offering a potential site of 'bottom-up conviviality (Rogaly, forthcoming), the degree to which difference is celebrated is on the surface unclear since Tomek refers only to Scottish, English and Italians suggesting a curious absence of non-Europeans in the mix (cf. Valentine, 2008). As Nayak (2017:299) eruditely argues, conviviality is not 'a given' in multicultural spaces, and such encounters are 'imbued with bumps, scratches and discordant white noise'. Furthermore, the website was set up as an 'alternative' to existing modes of Polish community in the city (i.e. the community centre) and is, thus, formed through a narrative of exclusion.

In 2016, Tomek's relationship to a Polish community had changed dramatically. He reflects here on this change remarking that the 'safety blanket' of early settlement has evolved into disparate networks of individuals, and the cutting of ties.

"There is no such a thing as Polish community... people, you know, media or like whoever, talkers, politics, they just try to say Polish community. Or some people claim they represent Polish community. This is a joke. There is no such a thing as Polish community because Polish community is as complex as a nation right... it's that belonging, that identity shifted a lot and it became much more personal probably. This paper is the 'accepted' version, now published in Transactions of the Institute of British Geographers 
And far less abstract. And those big identities, they upset me a lot now. They...they make me uncomfortable and I don't think I tick all the boxes of any group I belong to or being made belong, like, you know, gender wise, nation wise, social class wise or professionally. I just don't really feel that I fit anywhere fully... this radical new Europe. It's so upsetting because it doesn't allow for that. You have to belong here and there to this and that place or this and that group, you know, and have, wear this and that uniform. It's absolutely impossible"

Tomek discusses the challenges of belonging to a community that is rigidly defined by normative identity constructs. He rejects the 'big' identities of nation, gender and class as meaningless and feels like he doesn't 'fit'. The loss of key relationships within his Polish group of friends and the absence of reciprocity through friendship has deeply unsettled his sense of belonging (cf. Askins, 2016). In 2016, he revoked his initial claims that his Polish friends were like a makeshift family, suggesting 'It was just some temporary arrangement that was comfortable in the time' and revolved around short-lived encounters with sameness. The rupturing of some of Tomek's 'anchors' has set in motion deeper emotional frictions of identity and place, related also to life stage and mobility transitions and this impacts on the type of community he feels he belongs to. Here, Ryan's (2017) notion of differentiated (dis-) embedding is useful alongside Askins' (2016) 'emotional citizenry' to understand how time and emotion shape patterns of social integration and the nature of community. Tomek's perspective on community has changed from an energized narrative of potentiality to one of feeling disembedded, alienated and constrained.

\section{Community happening: the cultural festival}

This paper is the 'accepted' version, now published in Transactions of the Institute of British Geographers 
In 2007, Maria and her Polish friends (including Tomek and Łukasz) set up a collective to 'bring together our communities' by promoting Polish culture in Scotland at community festivals, theatre and visual art productions that 'speak in the voice of young Poland'. The collective was established as 'a voluntary network of Polish people most of whom are under 30 and all of those who work full time' (Maria, 2010). This was a self-conscious act of community formation by young people reflecting Staeheli's (2008) notion that community is made meaningful through 'practices and actions of the people who attempt to forge them'. A two-day festival of Polish culture took place in the city in 2009 to promote Polish culture to the Scottish public. It was a temporary site of encounter yet also a site of multiple temporalities. Firstly, the event was both youth-focused and an inter-generational bridge between different Polish migrant cohorts, organized by young people to celebrate and re-enact Polish heritage rituals and traditions. The compatibility of the traditional and progressive make visible the 'alternative continuities' that shape community practices and encounters (Sanadjian, 1995). Secondly, festival volunteers narrated 'community' as nostalgia alongside present needs to find stability amidst the transitions of mobility. Maria represented her current community activism in relation to memories of childhood and a reconnection with the past.

"I would like to live in a small town, peaceful, just like my childhood really, maybe that's what it is. Even though people quarrel and have misunderstandings they are stuck in this place, they have to work, not 'I've had enough, I'm changing myself, changing my scene now'. The community is responsibility, the responsibility of living in a place and being responsible for people around you" (Maria, aged 30, 2010).

This paper is the 'accepted' version, now published in Transactions of the Institute of British Geographers 
Maria associates community with 'responsibility' and the being fixed in place rather than the transient fluidity associated with a mobile life. For Maria, community requires the 'habits of mutual obligation' (Williams, 1984) that are not so present in the shifting and impatient transitions of dwelling in cities or living a mobile life. She goes on,

"If you are emigrating you have the mindset that I am here for a short time so why should I bother to build or put down roots...it's not like there's great community spirit [in Scotland]...I know my neighbours...but it's such a constant mix and constant change, there is no boundaries - that's the problem of the cities I think" (Maria, aged 30, 2010).

Fleeting encounters with neighbours does not constitute community to Maria, who later remarked that 'the last people you would go and see in a pub would be your neighbours'. Here time and mobility are key to understanding the relational practices of community. For Maria, the rhythm of the city impedes a sense of community, echoing traditional notions of community as village life where life 'flows more slowly, more habitually and more evenly' (Simmel, 2002:409) ${ }^{\mathrm{iii}}$. Conversely, mobility appears to be the very thing that drives a 'will to connect' (ibid.) as the 'frictions' of mobility are a key motivation for developing the festival.

“...these people wanted to feel they were important, they wanted to feel that they can do it because they were all in the same stage of mind as me, they were frustrated doing jobs really below their qualifications" (Maria, aged 30, 2010).

This paper is the 'accepted' version, now published in Transactions of the Institute of British Geographers 
The blockages to occupational mobility are frictions that slow down or immobilize migrants at work, yet they also galvanize collective fears and frustrations. Friction, thus, simultaneously 'hinders and enables mobilities' (Cresswell, 2014:113). Maria's prior attachments to places and people are reinvigorated through active engagements with her 'community' where she re-interprets traditional notions of belonging through new embodied forms of social solidarity. Staeheli et al. (2012) argue that in the absence of formal citizenship rights, community becomes a space where categories of belonging can be contested, debated and co-created. The positioning of migrants as outsiders in relation to others in a community does not need to be legally enshrined to be emotionally and affectively felt (Askins, 2016; Rogaly, forthcoming). As Brexit unfolds, embodied acts of citizenship-cum-community have been energized as EU citizens contest the negotiation process. UK-wide campaigns, such as 'One Day Without Us' and 'the 3 million' have been important for demonstrating migrant political agency yet they remain wedded to neoliberal logics of contribution. This language of recognition and contribution was already in process in 2010. Łukasz, a festival volunteer, prides himself on becoming active in the local community and contributing'.

"That got me really proud...It felt nice, you know, the random event that doesn't normally happen organised by a migrating force of minority, the local people being interested in it, not looking at something that represents a bunch of people who came to steal benefits and jobs but something that contributes to society as well" (Lukasz, age 28, 2010).

This paper is the 'accepted' version, now published in Transactions of the Institute of British Geographers 
Łukasz displays pride at the 'force' of his community to offer an alternative representation of Polish migration, yet the frictions are clear. Reflecting his earlier disavowal of 'other' Poles, Łukasz stakes a powerful claim to representation in relation to 'other' community practices in the city as well as wider national discourses of the Polish migrant. The desire to show contribution is, arguably, a strategy of integration in the context of these discourses and points to a range of neoliberal logics that authorise and validate only those encounters aimed at easing public perceptions of migration. As such the festival is a site of uncomfortable politics in which the 'grip of encounter' is made up of “awkward, unequal, unstable, and creative qualities of interconnections across difference" (Tsing, 2004, cited in Cresswell, 2014:113).

Finally, whilst the festival was a temporary, purpose-driven community practice intended to perform an acceptable 'micro-public' of new migration (Amin, 2002), it also demonstrates an ongoing negotiation of the unstable politics of mobility and citizenship. Drawing on Waite et al. (2014), Askins (2016:518) writes that even an 'affirmative politics of recognition' tends to rely on fixed notions of citizenship based on 'reductive modes of belonging' that focus on 'only-difference'. Re-focusing on the emotionality of such encounters, she argues, helps to see a more complex and intersectional view of difference-and-similarity, a more 'hopeful' interpretation of how individuals enact solidarities in everyday life. After the festival finished, Maria reflected 'I can't believe we did it', and all these people are still connected, they are still networked'. The continuation of these networks shows community practices as not simply fleeting moments of interaction, but accumulative processes with potential to be meaningful foundations for deeper sense of being-in-common (cf. Wilson, 2016). Furthermore, in seeking to formalize the Polish community as diaspora in this This paper is the 'accepted' version, now published in Transactions of the Institute of British Geographers 
way is a collective claim to citizenship. Such claims for power are made through everyday forms of relating characterized by emotionality, agency and potentiality (Askins, 2016; Rogaly, forthcoming; Staeheli et al., 2012).

In the wake of Brexit, however, Maria reflects despondently on the meaning of formal community networks in relation to wider political disenfranchisement.

"You had this beautiful, diverse community policy for 4, 5 years...encourage migrants to open the organisations and build integrations blah, blah - for what? I have worked for, like, 7 years ...built the association, and just when we decide ok we'll go professional, thre's no need for our work anymore. Well, maybe there is, but I don't feel like doing it because I don't have a heart in it anymore... we are third category citizens" (Maria, age 37, 2016)

This extract contradicts Maria's earlier narrative in which she seeks community at times of politically-induced personal crisis. Here, she laments having to conform to the shifting national priorities that shape the governance of community. The vote for Brexit paralyzed community mobilization as rights to mobility and citizenship were put under scrutiny for EU nationals. Feeling this loss of power, Maria appears to have re-scaled her energies away from formal, public community practice to the informal, private networks at home and through friendships where she finds more immediate emotional support. Yet, this is also a political act as she carves out spaces of solidarity in relation to a hurtful public debate, absenting herself in an act of resistance. Echoing Askins (2016), Maria's search for mutual recognition is both political and emotional,

This paper is the 'accepted' version, now published in Transactions of the Institute of British Geographers 
it is multi-sited and is negotiated across different time-spaces (see also Koefoed and Simonsen, 2012).

\section{Conclusion}

I have used Polish nationals' own definitions and experiences of community to present a grounded and relational analysis of community. There are contradictions inherent in these narratives that simultaneously celebrate and denigrate community; that refer to it as meaningless, yet lament its loss. A relational perspective is significant for unravelling the contradictory and shifting temporalities and spatialities of community practice whilst also seeking to understand why the discourse of community remains so powerful. The empirically-driven analysis in this paper shows the potential of a relational perspective in applied studies of community, particularly how it can be operationalized to research the structural, discursive and performative together.

The paper draws on diverse scholarship on the geographies of encounter, mobility and citizenship that has foregrounded relational thinking in order to conceptualise community differently. First, in order to overcome spatially and temporally rigid dichotomies of communal experience (Studdert and Walkerdine, 2016), community should be understood as a dynamic, interconnected and power-laden process. I have explored diverse mutations and transgressions of spatial and scalar relations in the practice of community among Polish nationals in Scotland. The establishment of community events themed around the Polish nation, energized by trans- or multiThis paper is the 'accepted' version, now published in Transactions of the Institute of British Geographers 
national encounters in local spaces points to a scalar complexity of migrant community formation and connects to debates on re-scaling encounters, conviviality and citizenship. However, encounters are also spatially contingent and differentiated, punctuated by long-standing, intersectional hierarchies and competing resources that frame meanings of community internally and externally.

Second, there are multiple temporalities of community. In seeking to overcome intergenerational conflict between the different Polish migrant cohorts, Polish nationals create 'alternative continuities' bridging past and present narratives of Polishness for potential futures of solidarity. Attention to critical temporalities of migrant community helps to reject ideas that the temporariness associated with economic migration means community 'lost'. Rather, community is understood as an 'emergent' set of relations, paced differentially across the lifecourse. Issues of power and governance of community (internally and externally) are also key to the rhythms of community as, for example, political processes like Brexit halt or slow down community energies. Third, mobility is integral to understanding community as relational. Community is made meaningful by the mobile interactions of people, places and objects. I have drawn on the concept of 'moorings' to discuss the physical infrastructures of community life ranging from the physical buildings in which people meet to technological platforms that enable virtual interactions (Urry, 2007). Moorings may be static structures but they are, at the same time, enabling particular forms of movement (imaginative, communicative, physical, emotional etc.) that shape community practices. Alongside this, community involves frictions of mobility and the 'sticky materiality of practical encounters' (Tsing, 2004) that are affective and

This paper is the 'accepted' version, now published in Transactions of the Institute of British Geographers 
emotional, happen at particular places and times and are marked by various intersectionalities.

In her speech on Brexit at London's Mansion House, Theresa May pledged that 'no community in Britain would ever be left behind again' and argued for a 'stronger, more cohesive nation' (May, 2018). As Brexit unfolds and the rights and status' of EU citizens are determined, exactly who may be, or feel, 'left behind' remains to be seen. Communities in Britain are being re-politicised through the governing rhetoric of Brexit negotiations and through ongoing struggles for citizenship in everyday spaces at a range of scales. In this context, questions regarding the effects of Brexit 'dissensus' on modes of relating are key to understanding new dynamics of migration, integration and 'emotional citizenry'. Researching governance after Brexit will require rigorous analytical frameworks and innovative methodologies that interrogate the interconnections between discourses of Brexit, migration and integration, local practices and encounters and private and emotional meanings of community for individuals. A relational perspective offers rich resources to analyse these developments as power-laden, interconnected processes across space, time and scale to better understand questions of how power is negotiated and contested by difference actors through the politics of Brexit and migration.

\section{References}

Adey, P. (2006) 'If mobility is everything then it is nothing: towards a relational politics of (im)mobilities', Mobilities, 1, 75-94.

This paper is the 'accepted' version, now published in Transactions of the Institute of British Geographers 
Adey, P. and Bevan, P. 2006. "Between the physical and the virtual: connected mobilities,". In Sheller, M and Urry, J (Eds). Mobile Technologies of the City. London: Routledge

Amin A (2002) Ethnicity and the multicultural city: Living with diversity. Environment and Planning A 34: 959-980.

Anderson, J. (2012) Relational places: the surfed wave as assemblage and convergence. Environment and Planning D 30(4):570-583

Anderson, J. and Wilson, H. (2017) Everyday Brexits. Area.

DOI: $10.1111 /$ area.12385

Askins, K (2016) Emotional citizenry: everyday geographies of befriending, belonging and intercultural encounter. Transactions of the Institute of British Geographers 41(4):515-527

Askins K and Pain R (2011) Contact zones: Participation, materiality, and the messiness of interaction. Environment and Planning D 29(5): 803-821.

Bastian, M. (2014) Time and community: a scoping study. Time \& Society 23(2):137166

Beck, U. (2006) Cosmopolitan Vision. London: Wiley

This paper is the 'accepted' version, now published in Transactions of the Institute of British Geographers 
Bissell, D. and Fuller, G. (2010) Stillness in a Mobile World. London: Routledge

Brown, J. (2011) Expressions of diasporic belonging: the divergent emotional geographies of Britain's Polish communities. Emotion, Space and Society. 4:229-237

Burrell, K. (2006) Moving Lives: Narratives of Nation and Migration among Europeans in Post-War Europe. London: Routledge

Burrell, K. (2009) (ed.) Polish Migration to the UK in the 'New' European Union: After 2004 . Farnham: Ashgate

Burrell, K. (2010) Staying, Returning, Working and Living: Key Themes in Current Academic Research undertaken in the UK on Migration Movements from Eastern Europe', Social Identities, 16:3, 297-308

Calhoun, C. (1998) Community without propinquity revisited. Sociological Inquiry $68(3): 373-7$

Cater, J and Jones, T (1989) Social Geography: An Introduction to Contemporary Issues. London: Edward Arnold

Clarke, H.; Goodwin, M. and Whiteley, P. (2017) Brexit: Why Britain Voted to Leave the European Union. Cambridge: Cambridge University Press

This paper is the 'accepted' version, now published in Transactions of the Institute of British Geographers 
Cresswell, T. (2010) Towards a politics of mobility. Environment and planning D 28(1), 17-31.

Cresswell., T. (2014) Friction. IN: P. Adey, D. Bissell, K. Hannam, P. Merriman, and M. Sheller (eds) Routledge Handbook of Mobilities. London: Routledge

Crow, G and Allen, A (1994): Community Life: An Introduction to Local Social Relations. Harlow: Pearson Education

Coulthard G (2014) Red skin, white masks: rejecting the colonial politics of recognition University of Minnesota Press, Minneapolis MN

Darling, J and Wilson, HF (eds) (2016) Encountering the City: Urban Encounters from Accra to New York. London: Routledge

Engbersen, G. and Snel, E. (2013). Liquid migration: Dynamic and fluid patterns of post-accession migration. In B. Glorius, I. Grabowska- Lusinska, \& A. Rindoks (Eds.) Mobility in transition: Migration patterns after EU enlargement (pp. 21-40). Amsterdam: Amsterdam University Press.

Fox, J.E., Moroşanu, L. and Szilassy, E. (2012) The Racialization of the New European Migration to the UK. Sociology 46(4): 680 - 695

Frankenberg, R. (1966) Communities in Britain. Middlesex: Penguin

This paper is the 'accepted' version, now published in Transactions of the Institute of British Geographers 
Galaśinska, A. (2010) Gossiping in the Polish club: an emotional coexistence of 'Old' and 'New' migrants. Journal of Ethnic and Migration Studies 36(6):939-51

Garapich, M. (2008a) Odyssean Refugees, Migrants and Power - Construction of 'Other' within the Polish 'Community' in the UK. In: Brettell, C. And Reed-Danahay, D. (eds) Citizenship, Political Engagement and Belonging: Immigrants in Europe and the United States. Rutgers University Press, pp.124-44

Garapich, M. (2008b) The migration industry and civil society: Polish immigrants in the UK before and after EU enlargement. Journal of Ethnic and Migration Studies 34(5): $735-52$

Garapich, M. and Eade, J. (2009) Settling or Surviving in London? The Experience of Poles and Other A8 Migrants in a Global City Borough. In Eade, J. and Valkanova, Y (eds.) Accession and Migration: Changing Policy, Society and Culture in an Enlarged Europe. Aldershot, Ashgate

Gilroy, P. (2004) After empire: melancholia or convivial culture? London: Routledge

Grzymała-Kazłowska, A. (2005) From ethnic cooperation to in-group competition:

Undocumented Polish workers in Brussels. Journal of Ethnic and Migration Studies

Grzymała-Kazłowska, A. (2015) Social Anchoring: Immigrant Identity, Security and Integration Reconnected? Sociology 1-17.

This paper is the 'accepted' version, now published in Transactions of the Institute of British Geographers 
Hannam, K., Sheller, M. and Urry, J. (2006) Mobilities, immobilities and moorings. Mobilities 1(1): 1-22

Horschelmann, K. and El Refaie, E. (2014) Transnational citizenship, dissent and the political geographies of youth. Transactions of the Institute of British Geographers $39: 444-56$

Hough, A. and Whitehead, T. (2011) New Eastern European 'benefit tourism' fears after migrant safeguards scrapped. The Telegraph, $3^{\text {rd }}$ March 2011

Jones, M. (2009) Phase space: geography, relational thinking, and beyond. Progress in Human Geography 33(4):487-506

Kenyon E (2000) Time, temporality and the dynamics of community. Time \& Society 9: $21-41$.

Koefoed, L and Simonsen, K. (2012) (Re)scaling identities: embodied others and alternative spaces of identification. Ethnicities 12(5):623-42

Leitner H (2012) Spaces of encounters: Immigration, race, class, and the politics of belonging in small-town America. Annals of the Association of American Geographers 102: 828-846.

This paper is the 'accepted' version, now published in Transactions of the Institute of British Geographers 
Lulle A, Moroşanu L, King R. (2017) And then came Brexit: Experiences and future plans of young EU migrants in the London region. Population, Space and Place. https://doi.org/10.1002/psp.2122

Mackinnon, D. (2010) Reconstructing scale: towards a new scalar politics. Progress in Human Geography 35(1):21-36

Marston, S. (2000) The social construction of scale. Progress in Human Geography $24,219-42$

Massey D (2005) For Space. London: SAGE.

Matejskova, T, Leitner, H (2011) Urban encounters with difference: The contact hypothesis and immigrant integration projects in eastern Berlin. Social \& Cultural Geography 12: 717-741

McCollum, D., Nowok, B. and Tindel, S. (2014) Public attitudes towards migration in Scotland. Scottish Affairs 23(1):79-102

McGhee, D., Heath, S. and Trevena, P. (2012) Dignity, Happiness and Being Able to Live a 'Normal Life' in the UK Social Identities 18 (6): 711-727

McGhee, D., Moreh, C., \& Vlachantoni, A. (2017). An ‘undeliberate determinacy'? The changing migration strategies of Polish migrants in the UK in times of Brexit. Journal of Ethnic and Migration Studies 43(13): 2109-2130.

This paper is the 'accepted' version, now published in Transactions of the Institute of British Geographers 
Moskal, M. (2014) Polish migrant youth in Scottish schools: conflicted identity and family capital. Journal of Youth Studies 17(2): 279-291

Nayak, A. (2017) Purging the nation: race, conviviality and embodied encounters in the lives of British Bangladeshi Muslim young women. Transactions of the Institute of British Geographers 42(2):289-303

Noble G and Poynting S (2010) White lines: the intercultural politics of everyday movement in social spaces Journal of Intercultural Studies 31 489-505

Park, R. and Burgess, E (1967) The City. Chicago: UoC Press

Phillips, D. (2010) Minority ethnic segregation, integration and citizenship: A European perspective. Journal of Ethnic and Migration Studies 36(2):209-25

Phillips, D. and Robinson, D. (2015) Reflections on migration, community and place. Population, Space and Place 21: 409-420

Piętka-Nykaza, E., and McGhee, D. (2016). EU post-accession Polish migrant's trajectories and their settlement practices in Scotland. Journal of Ethnic and Migration Studies, 1-17

Putnam, R. D. (2001) Bowling Alone: The Collapse and Revival of American Community. New York, Simon and Schuster

This paper is the 'accepted' version, now published in Transactions of the Institute of British Geographers 
Rabikowska, M. and Burrell, K. (2009) The Material Worlds of Recent Polish Migrants: Transnationalism, Food, Shops and Home. In: Burrell, K. (ed) Polish Migration to the UK in the 'New' European Union. Farnham, Ashgate, pp.211-32

Rishbeth, C. and Rogaly, B. (2017) Sitting outside: conviviality, self-care and the design of benches in urban public space. Transactions of the Institute of British Geographers. ISSN 0020-2754

Rogaly, B. (forthcoming) Re-scaling citizenship struggles in provincial urban England. In: Darling, J and Bauder H (eds) From Nation to City: Rescaling Migration, Citizenship and Rights. Manchester: UoM Press

Rogaly, B. and Taylor, B. (2009) Moving Histories of Class and Community. Basingstoke: Palgrave Macmillan

Ryan, L. and D'Angelo, A., (2017) Changing times: Migrants' social network analysis and the challenges of longitudinal research. Social Networks. http://dx.doi.org/10.1016/j.socnet.2017.03.003

Ryan, L. (2009) Transnational Relations: Family Migration among Recent Polish Migrants in London. International Migration 49(2):80-103

Ryan, L. (2010) Becoming Polish in London: negotiating ethnicity through migration. Social Identities 16(3): 359-76

This paper is the 'accepted' version, now published in Transactions of the Institute of British Geographers 
Ryan, L. (2017) Differentiated embedding: Polish migrants in London negotiating belonging over time. Journal of Ethnic and Migration Studies Doi: 1080/1369183X.2017.1341710

Ryan, L., Sales, R. and Tilki, M. and Siara, B. (2008) Social networks, social support and social capital: the experiences of recent Polish migrants in London. Sociology 42(4):672-90

Rzepnikowska, A. (2016) Convivial Cultures in Manchester and Barcelona: experiences of Polish women. Studia Migracyjne - Przeglad Polonijny, 2(160): 119134

Sanadjian M (1995) Temporality of "home'” and spatiality of market in exile: Iranians in Germany. New German Critique 64: 3-36.

Sheller, M. and Urry, J. (2006) The new mobilities paradigm. Environment and Planning A, vol. 38, pp.207-26

Simmel, G. [1903] 2002. The Metropolis and Mental Life. In: G. Bridge and S. Watson (eds) The Blackwell City Reader. Oxford: Blackwell

Smith, N. (1993) Homeless/global: scaling places. In: Bird J, Curtis B, Putnam T, et al. (eds) Mapping the Future: Local Cultures, Global Change. London: Routledge pp. $87-119$

This paper is the 'accepted' version, now published in Transactions of the Institute of British Geographers 
Smith, N. (2004) Scale bending and the fate of the national. In: Sheppard E, McMaster RB (eds) Scale and Geographic Inquiry: Nature, Society and Method. Oxford: Blackwell, 192-212

Staeheli, L.A. (2008) Citizenship and the Problem of Community. Political Geography 27:5-21.

Staeheli, L., Ehrkamp, P., Leitner, H. and Nagel, C. (2012) Dreaming the ordinary: daily life and the complex geographies of citizenship. Progress in Human Geography $36(5): 628-44$

Stenning, A. and Hörschelmann, K. (2008) History, geography and difference in the post-Socialist world: Or do we still need post-socialism? Antipode 40(2): 312-335

Studdert, D. and Walkerdine, V. (2016) Rethinking Community Research: Interrelationality, Communal Being and Commonality. London: Palgrave Macmillan

Thrift, N. (2004) Intensities of feeling: towards a spatial politics of affect. Geografiska Annaler: Series B 86, 57-78

Tönnies, F. [1877] 1957. Community and Society. Mineola, NY: Dover.

Tsing, A.L. (2004) Friction: an ethnography of global connection. Princeton University Press

This paper is the 'accepted' version, now published in Transactions of the Institute of British Geographers 
Todorova M (2005) The trap of backwardness: modernity, temporality, and the study of eastern European nationalism. Slavic Review 64: 140-164.

Urry, J. (2007) Mobilities, London: Sage

Valentine, G (2001) Social Geographies: Society and Space. Harlow: Prentice Hall

Valentine G (2008) Living with difference: Reflections on geographies of encounters. Progress in Human Geography 32(3): 323-337.

Valentine, G, and Sadgrove, J (2012) Lived difference: A narrative account of spatiotemporal processes of social differentiation. Environment and Planning $A$ 44: 2049.

Vertovec, S. (2001) Transnationalism and identity. Journal of Ethnic and Migration Studies: 27(4): 573-582

White, A. (2011) Polish Families and Migration since EU Accession. Bristol: Policy Press

Williams, R. (1989) The Importance of Community In: Williams, R. Resources of Hope. London, Verso, pp.111-19

This paper is the 'accepted' version, now published in Transactions of the Institute of British Geographers 
Wilson, H.F. (2016) On geography and encounter: Bodies, borders, and difference.

Progress in Human Geography 41(4):451-71

Woodyer, T. and Geoghegan, H. (2013) (Re)enchanting geography? The nature of

being critical and the character of critique in human geography. Progress in Human

Geography 37(2): $195-214$

Young IM (1986) The ideal of community and the politics of difference. Social

Theory and Practice 12: 1-26.

\footnotetext{
${ }^{\mathrm{i}}$ Studdert and Walkerdine (2016) draw on Arendt to theorise community, asserting that only through her reading of the human condition can one see 'the active assertion of plurality and interrelationality'.

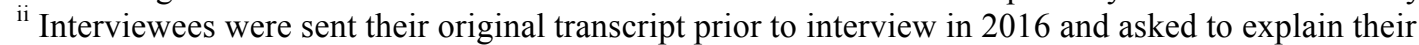
perceptions of biographical changes over time. Additional questions relating to the Brexit vote were added to allow comparability and extension of the 2010 interviews.

${ }^{\text {iii }}$ Simmel (2002) compares the brief, fleeting interaction of people in the metropolis with the "social intercourse' of the small town positing that the city consists of restless, fragmentary systems of relationships in which individuals are liberated from historical bonds and experience 'full freedom of movement'.
}

This paper is the 'accepted' version, now published in Transactions of the Institute of British Geographers 